\title{
THE EFFECT OF USING FLASHCARDS ON STUDENT' VOCABULARY MASTERY
}

\author{
RIRYN FATMAWATY \\ fatmawatyriryn@ymail.com \\ Universitas Islam Lamongan
}

\begin{abstract}
:
As we know that vocabulary is as a major component of language learning. Without having adequate vocabulary we will get difficulty to learn English. So that way it has to be mastered by learners. It should be the first priority in English language teaching and learning because as a central of language teaching and learning. It means that by mastering vocabulary, of course with grammar, the learners will produce so many sentences easily either in spoken or written one. Actually, there are many methods that used by teacher in English's teaching in order to reach the goal in teaching and learning English, such as using cartoon movies, pictures, jigsaws, games, song and etc. Another way is learning through vocabulary card or flashcard. As we listen and read, we often meet new words by flashcard. A flashcard is a set of cards bearing information, as words or numbers, on either or both sides, used in classroom drills or in private study". The problem of the study is the students vocabulary mastery of MI. Babul Ulum Dorogede Gedangan Sukodadi Lamongan is very low, so researcher does a research in that school in a month, there are two meetings for doing pre test and post test, while four time for teaching and learning activities for each class by using flashcard. In doing research, the experimental class were given several treatments, while the control group get the lesson as usual. The topics lessons, teacher, pre-test and post test were same, but the method of teaching was different.

Based on the result of statistic test, it is known that the result scores of experiment class is higher than control class and it is described as follows; based on the normality test, that the result from experiment class is $(-2,7756<11,3449)$, and from control class is $(-19,6799<$ 11,3449). That means $\mathrm{HO}$ received, both samples is from population distributes normal. Based on the homogeneity test is $(2,25<3,69)$, that HO us received. So that, both samples is from variant homogeneity. Based on the differences between mean with the t-test, that is $(2,12<6,69)$, means that HO is refused. So, the final score of students who taught by using flashcard is better than the students who do not use.
\end{abstract}

Keywords: Flashcard, Vocabulary mastery

\section{Background of The Study}

Actually, there is big problem in students' vocabulary mastery in the school MI. Babul Ulum Dorogede Gedangan
Sukodadi Lamongan. Students are very low in their vocabulary mastery. They disable to tell some words or meanings even it is the simple word. They also 
difficult to pronoun and write it, whereas, in general the students must have enough words since their child. As cited William, "During early childhood, children learn vocabulary at the rate of approximately 2,000 to 4,000 words per year (Brabham \& Villaume, 2002; Nagy, Anderson, \& Herman, 1987) it means that children can memorize vocabulary 5-10 words a day. How is the condition in our country? As researcher's experience in that school, students learn vocabulary at the rate 10 to 20 words a day but they have memorized only 5-10 words and they forgot in after. Of course, this problem has to handle as soon as possible.

As known, the problem is not only happens in the first but also in other class. Researcher indicates it is caused by some reasons. First of all, it is caused by the method of teaching and learning that less interest for student. Second, it is caused less motivation. The problem is students consider that English is difficult, they do not have word to say or have word but disable to pronoun it, so they are not confident. Nation (2001) stated," Without an extensive knowledge of vocabulary and strategies for learning new words, learners may feel disappointed and lose their confidence". This condition caused them lazy to study. In the process of teaching and learning, researcher often find situations when students are not motivated because they got bored, if they are bored or emotionally upset they will find it difficult to concentrate and participate in the classroom activity. The last, the school is very less in some facilities. Actually, there is not language laboratory, some computers and etc. There is a little library but the books are vey less. So, the students cannot use the facilities, of course they cannot search and get information that they need.

Based on condition above, researcher thinks that solution of this problem is should any improvement in vocabulary. So that way researcher is very enthusiastic to take vocabulary subject as research material in this study, because, it is as the basic of language. It is as a major component of language learning. Laufer (1997) says,"that vocabulary learning is at the heart of language learning and language use. As we know, Language is a means of communication. People communicate with each other by using language. It brings idea, opinions, thoughts, and feelings. It is the first foreign language which is very important to transfer and gain knowledge, science and technology, art and culture, and establish international relationship. Douglas (2000:5) says, "Language is a system of arbitrary conventionalized vocal, written, gesture, symbols that permit members of a given community to communicate intelligibly with each other". Without having adequate vocabulary, the students will get difficulty to learn English. It is what makes the essence of a language.

Vocabulary learning is an intrinsic part of language teaching. As the basic components of the four language skills (listening, reading, writing and speaking) vocabulary has to be mastered by learners. Vocabulary should be the first priority in English language teaching and learning. It is central of language teaching and learning. It means that by mastering vocabulary, of course with grammar, the learners will produce so many sentences easily either in spoken or written one. Dewey (1910) says that vocabulary is critically important because a word is an instrument for thinking about the meanings 
which it expresses. They can also communicate with other people fluently and express their opinion or ideas conveniently. Vocabulary is necessary for communication and in expressing meaning through the productive and receptive skills, as cited William, Neuman \& Dwyer (2009:385) say that vocabulary can be defined as "the words we must know to communicate effectively: words in speaking (expressive vocabulary) and words in listening (receptive vocabulary)".

In the past of language teaching, vocabulary learning and teaching were given little importance. As Moir and Nation (2008) write, at one time it was widely assumed that lexical instruction is not essential as it can happen by itself; therefore, the teaching of vocabulary was not popular (Nation, 1990). However, nowadays, the significance of vocabulary and its significance in learning a language have become more accepted. Griffiths (2003, 2006) point out, for example, that recently the significance of teaching vocabulary has been acknowledged.

There are many methods that used by teacher in English's teaching in order to reach the goal, the student can speak English fluently such as using cartoon movies, pictures, jigsaws, games, song and etc. researcher try to apply another way. It is learning through vocabulary card or flash card. As we listen and read, we often meet new words by flash card. "A flashcard or flash card is a set of cards bearing information, as words or numbers, on either or both sides, used in classroom drills or in private study" (wikipedia).

One main advantage of flash cards is that they can be taken almost anywhere and studied when one has a free moment (Brown, 2000). Another is that they can be arranged to create logical grouping of the target words (Gairns \& Redman, op.cit.Cohen, 1990). Vocabulary flashcards are great tools for studying. They can be fun, colorful, and creative ways to aid in memory and retention of vocabulary words. Nicholson (1998) states that, "the positive effects of flash cards on language learning despite the fact that some researchers have argued that they should be used as a device to create fun classrooms".

Flashcard is great tools for studying. It can be fun, colorful, and creative ways to aid in memory and retention of vocabulary words. As cites Maryam, "some researchers indicate that working with flash cards help learners in acquiring vocabulary more effectively than word lists (Mondria \& Mondria-de Vries, 1994; Schmitt, 1995)". It can be seen that flash cards have been used for teaching a variety of purposes during the history of language teaching. An example is to help students to improve word recognition if they are poor readers (Culyer, 1988).

\section{Method}

This study is classified as experimental research. As defined by Arikunto (1998:03) states that it is a way to find the relation of cause-effect (causal relation) between two factors or to find the effect of a treatment. It is research that does an experiment to groups of experiment. Fuchan, A. (2004) states that," experimental research can be interpreted as an objective study, systematic, and controlled for predict or control phenomenon. The aim is to investigate causality (relationship effect and cause)." Experiment have two criteria: first, there are at least two groups included in the study, a control and experiment group; and second, the subjects are randomly assigned 
to one of those groups, Diane L, Freeman and Michael, (1991:20-21).

The opinion above related with true experimental research design because the writer can control all of other variables that influence the way of research, Sugiono (2008:75) says that the characteristic of this design is the sample that used for experiment and control group taken randomly. In here, both of experimental and control group chosen randomly by lottery. It means that the entire act, varieties or giving condition that would be scored or knew the influence (www.unhalu.ac.id, 2009).

Researcher does a research in MI.

Babul Ulum Dorogede Gedangan Sukodadi Lamongan in a month, there are two meetings for doing pre test and post test, while four time for teaching and learning activities for each groups. In doing research, the experimental group were given several treatments, while the control group get the lesson as usual. The topics lessons, teacher, pre-test and post test were same, but the method of teaching was different, using flashcatd used in the experimental group but not for control group.

The design of present study (non equivalent pre-test and post-test control group) can be illustrated as below:

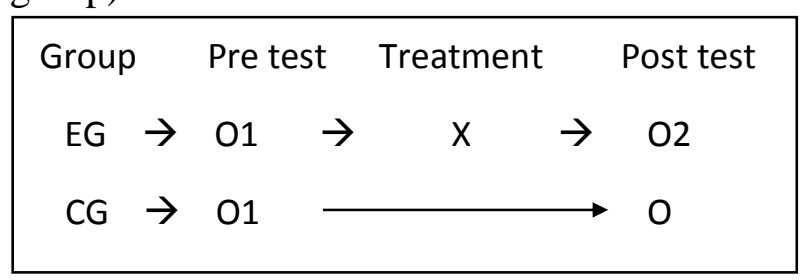

Note:

$\begin{array}{ll}E G & : \text { Experimental group } \\ C G & : \text { Control group } \\ \text { O1 } & : \text { Observation 1-pre test } \\ \text { O2 } & : \text { Observation } 2-\text { post test } \\ X & : \text { Treatment }\end{array}$

There are several steps that the writer will do to collect the data in MI. Babul Ulum Dorogede Gedangan Sukodadi Lamongan. To collect the data, the researcher gives pre test, the post test and several treatments to the two classes ( $\mathrm{A}$ and $\mathrm{B}$ ). The writer will give the treatment four times in three weeks. The pre test will be given before students get the treatment, after that, will be given treatment. The post test did after treatment activity finish.

In this study, the data is from quantitative data named test score. This analysis used some statistic test such as; the normality test, the homogeneity test, the differences between means and t-test. The explanation as follows:

\section{The Normality Test}

Subana (2000:123-126) states that is a test to measure whether or not the data (sample) from the population distributes normal. The procedures of this test as follows:

a. Making distribution frequency list of each group

b. Determining alpha of each class

c. Calculating mean $\bar{x}=\frac{\sum_{i=1}^{n} x_{i}}{n}$

d. Calculating standard deviation

$$
s^{2}=\frac{\sum\left(x_{i}-\bar{x}\right)^{2}}{n-1}
$$

Note:

$\bar{x}=$ Final score of mean

$x_{i}=$ Mean score

$\mathrm{n}=$ Many data

e. Calculating list of expectation frequency. The procedures are as follows: 


\section{Determining}

under limits $\left(x_{i}\right)$ of each interval Class limit $=\mathrm{x}-0,5=(\mathrm{BK} 1,2 \ldots)$

Calculating

standard number $\left(z_{i}\right)$ of each interval

$$
z_{i}=\frac{x_{i}-x}{s} ; \text { for } \mathrm{I}=1,2,3 \ldots n
$$

Note:

$Z_{i}=$ Standard number

$X_{i}=$ Under limits I class

$\bar{x}=$ Mean of score (from frequency distribution)

$\mathrm{s}=$ Standard deviation (from frequency distribution)

Calculating wide of each class interval $(L)$

Calculating

expectation frequency: $\left(E_{i}\right)=L . n$

Note:

$E_{i}=$ Expectation frequency

$\mathrm{L}=$ Area of each interval class

$\mathrm{n}=$ Many data

f. Determining Hypothesis

$H_{0}$ : Sample is from population distributes normal

$H_{1}$ : Sample is from population does not distributes normal

g. Determining alpha $(\alpha)$

h. Calculating the value of $x^{2}$ by chi square, the formula is as follows:

$$
x^{2}=\sum_{i=1}^{k} \frac{\left(O_{i}-E_{i}\right)^{2}}{E_{i}}
$$

Note:

$\mathrm{k}$ = Many interval classes

$O_{i}=$ Research frequency

$E_{i}=$ Expectation frequency i. Looking for the value from $x^{2}(1-\alpha)(k-3)$

j. Determining experiment criteria:

$H_{0}$ is received if $x_{h i t}^{2},<x^{2}(1-\alpha)(k-3), \quad$ therefore sample distributes normal

$H_{1}$ is refused if $x_{h i t}^{2}$ $\geq x^{2}(1-\alpha)(k-3)$, therefore sample does not distribute normal

k. Concluding

\section{The Homogeneity Test}

As defined by Ma'unah that homogeneity test is comparison of the biggest and the smallest variants. The researcher uses variants homogeny test by Hartley test, the formula is:

$$
F=\frac{S_{\text {big }}^{2}}{S_{\text {small }}^{2}}
$$

The procedure is as follows:

a. Arranging Hypothesis

$H_{0}$ : Sample is from population that has variants homogeneity

$H_{1}$ : Sample is from population that has not variants homogeneity

b. Determining alpha $(\alpha)$

c. Calculating test statistic

$F_{\text {hit }}=\frac{S_{\text {big }}^{2}}{S_{\text {small }}^{2}}$

$F_{\text {tabel }} ; \mathrm{F} ; \mathrm{s}$ big, $n$ small

$F_{\text {hit }} F_{\text {tabel }}=H_{0}$ is refused

d. Concluding

\section{The differences between Means}

This study is used one side namely right side: If the classes distribute normal by variant homogeneities, therefore test procedures are as follows:

a.

Determining Hypothesis 
$H_{0}$ : The final score of students who have been taught by using flashcard have increasing in students' vocabulary mastery than those taught by non-using flashcard

$H_{1}$ : The final score of students who have been taught by using flashcard have not increasing in students' vocabulary mastery than those taught by non-using flashcard

b. Determining alpha $(\alpha)$

c. Determining receiving criteria $H_{0}$

$H_{0}$ is received if $t_{h i t}(\alpha, v)$

In contrast $H_{0}$ is refused

d. Calculating test statistic, the formula is:

$t_{\text {hit }}=\frac{\bar{x}_{1}-\bar{x}_{2}}{\sqrt{\frac{s_{1}^{2}}{n_{1}}+\frac{s_{2}^{2}}{n_{2}}}}$

With $v=\frac{\left(\frac{s_{1}^{2}}{n_{1}}+\frac{s_{2}^{2}}{n_{2}}\right)^{2}}{\frac{\left(S \frac{2}{S^{2} / n_{1}}\right)^{2}}{n_{1}-1}+\frac{\left(\begin{array}{ll}S & 2 \\ n_{2}\end{array}\right)^{2}}{n_{2}-1}}$

Note:

$\overline{x_{1}}=$ Mean score sample 1

$\overline{x_{2}}=$ Mean score sample 2

$n_{1}=$ Many of sample data 1

$n_{2}=$ Many of sample data2

$S_{1}^{2}=$ Sample variants 1

$S_{2}^{2}=$ Sample variants 2

\section{Result and Discussion}

In preliminary study that was done before the research, the researcher collected the data from the teacher who teach the class. Then the rearcher got some data. There are some difficulties in doing research. In that school there is not facilities that can help activity of teaching and learning, such as; electronic media, books and etc. So, researcher used her own notebook for presenting the using flashcard, brows the materials in internet also made the cards.

The researcher conducted two kinds of tests, pre and post test. It is for both of class, experiment and control class. Pre test held before treatment and it to know or measure the vocabulary mastery of the students. Post test held after treatment and it to know success or not method that applied by the researcher by using flashcard. Pre test given to both of groups before researcher applies flashcard. Researcher made the test and it consist 10 numbers Researcher also got the students' score of pre test, the average score of both of class was only 62 . This score was still low. It could be seen in the table as follows. From that table it could be concluded that students' score was very low, so it could be assume that their vocabulary mastery was very poor.

\begin{tabular}{|l|c|c|}
\hline No & $\begin{array}{c}\text { Score of Control } \\
\text { Group }\end{array}$ & $\begin{array}{c}\text { Score of Experiment } \\
\text { Group }\end{array}$ \\
\hline 1 & 55 & 50 \\
\hline 2 & 50 & 55 \\
\hline 3 & 60 & 55 \\
\hline 4 & 50 & 70 \\
\hline 5 & 75 & 75 \\
\hline 6 & 65 & 65 \\
\hline
\end{tabular}




\begin{tabular}{|l|l|l|}
\hline 7 & 80 & 80 \\
\hline 8 & 60 & 50 \\
\hline 9 & 60 & 55 \\
\hline 10 & 60 & 85 \\
\hline 11 & 50 & 80 \\
\hline 12 & 50 & 60 \\
\hline 13 & 65 & 55 \\
\hline 14 & 55 & 85 \\
\hline 15 & 65 & 60 \\
\hline 16 & 75 & 75 \\
\hline 17 & 55 & 70 \\
\hline 18 & 60 & 55 \\
\hline 19 & 55 & 50 \\
\hline 20 & 60 & 55 \\
\hline 21 & 60 & 65 \\
\hline 22 & 65 & 50 \\
\hline 23 & 85 & 55 \\
\hline 24 & 60 & 55 \\
\hline 25 & 70 & 50 \\
\hline
\end{tabular}

Table 1. (Score of Both Groups)

After doing pre test, researcher given treatment. The other problem in the first meeting, students still were not motivated and lazy in the classroom, they were still difficult in memorizing vocabulary and poor pronunciation. But researcher tries to decrease that problem. Researcher given spirit for them, and entered a little fun story in order to get back fun classroom.

In presenting flashcard, researcher used real cards as object of learning, but seldom used notebook to introduce the vocabulary. It was supported one of strategies of teaching vocabulary by Gairns and Redman. In the choosing criteria of slecting vocabulary, researcher appropriated with the level of students. As explained before, the students vocabulary mastery were very low, they can memorize 3-5 words only. So that, researcher used common topics in teaching vocabulary such as; human body, flower and fruit, animals and food and drink. It was supported the ideas in selecting the criteria of vocabulary by Rosa.

The last part is conducting post test, the students' score of experiment class was changed, the average is 78 while control group get 68 . it showed that students who have been taught by using flashcard increased in their vocabulary mastery than who have not been taught by using flashcard.

Same with pre test, researcher made the test and its consist 10 numbers. The result showed that the score of experiment class is increase after given treatment by using flashcard while the score of control class is same with the score of pre test. The result as follow:

\begin{tabular}{|l|c|c|}
\hline No & $\begin{array}{c}\text { Score of } \\
\text { Control Group }\end{array}$ & $\begin{array}{c}\text { Score of } \\
\text { Experiment } \\
\text { Group }\end{array}$ \\
\hline 1 & 60 & 70 \\
\hline 2 & 50 & 80 \\
\hline 3 & 65 & 75 \\
\hline 4 & 60 & 80 \\
\hline 5 & 75 & 85 \\
\hline 6 & 70 & 75 \\
\hline 7 & 75 & 85 \\
\hline 8 & 60 & 75 \\
\hline 9 & 60 & 75 \\
\hline 10 & 60 & 90 \\
\hline 11 & 55 & 85 \\
\hline 12 & 55 & 75 \\
\hline 13 & 65 & 70 \\
\hline 14 & 55 & 90 \\
\hline 15 & 65 & 75 \\
\hline 16 & 80 & 80 \\
\hline 17 & 55 & 80 \\
\hline 18 & 60 & 75 \\
\hline 19 & 55 & 70 \\
\hline 20 & 60 & 75 \\
\hline 21 & 60 & 80 \\
\hline 22 & 70 & 75 \\
\hline & & \\
\hline
\end{tabular}




\begin{tabular}{|c|c|c|}
\hline No & $\begin{array}{c}\text { Score of } \\
\text { Control Group }\end{array}$ & $\begin{array}{c}\text { Score of } \\
\text { Experiment } \\
\text { Group }\end{array}$ \\
\hline 23 & 85 & 75 \\
\hline 24 & 70 & 80 \\
\hline 25 & 75 & 75 \\
\hline \multicolumn{2}{|c|}{ Table 2. (Score of Both Groups) } \\
\hline
\end{tabular}

\section{Conclusion}

Based on the result of statistic test, it is known that the result scores of experiment class is higher than control class and it is described as follows:

1) Based on the normality test, the result from experiment class is $(-2,7756<$ $11,3449)$, and from control class is ($19,6799<11,3449)$. That means H0 received, both samples is from population distributes normal

2) Based on the homogeneity test is $(2,25$ $<3,59)$, that H0 us received. So that both samples is from variant homogeneity.

3) Based on the differences between mean with the t-test is $(2,12<6,59)$, means that $\mathrm{HO}$ is refused. So, the final score of students who taught by using flashcard is better than the students who do not use.

According to the final result, researcher concludes that the effect of using flashcard on students' vocabulary mastery at the of MI. Babul Ulum Dorogede Gedangan Sukodadi Lamongan is good, we can see from students' score, pointing with the flashcard, students feel better, comfortable, fun and interest to the topic. Flashcard is attractive media for teaching and learning, especially in vocabulary. It can be alternative media for teacher in increasing students' vocabulary mastery.

\section{References}

Latief, Adnan. 2010. Metode Penelitian Pembelajaran Bahasa, UM Press:Malang

Arikunto, Suharsimi. 1998. Prosedur Penelitian, PT. Rieneka Cipta:Jakarta.

Berne, J. I., \& Blachowich, C. L. Z. 2008. What Reading Teachers Say about Vocabulary Instruction: Voices from the classroom. The Reading Teacher,

Brown, H. D. 2000. Principles of Language Learning and Teaching. (4th ed.) New York: Longman.

Brabham, E. G., \& Villaume, S. K. 2002. Vocabulary Instruction: Concerns and Visions. The Reading Teacher.

Collin Cobuild English Language Dictionary (1989)

Culyer, R. 1988. Using Single Concept Cards and Sentences for Affective and Effective Reading. Intervention in School \& Clinic.

Ervin, G. L. 1988. Purposeful Practice with the four-by-six Card: Quick, Convenient, and Communicative. Foreign Language Annals, 21(4), 337-339. [Online] Available: http://onlinelibrary.wiley.com/doi/10.1111 /j.1944-9720.1988.tb01078.x/pdfDewey (1910)

Gairns, R., \& Redman, S. 1990.Working with Words: A Guide to Teaching and Learning Vocabulary. Cambridge: Cambridge University Press.

Schmitt, N \&. McCarthy, M. (Eds.) 1997. Vocabulary: Description, Acquisition and Pedagogy. Cambridge: Cambridge University Press. 
Griffiths, C. 2003. Patterns of Language Learning Strategy Use. System, 31, 367383. ISSN: 0346251X

http://dx.doi.org/10.1016/S0346251X(03)00048-4

Griffiths, C. 2006. Language Learning Strategies: Theory and Research. Iran. ILI Language Teaching Journal.

Harmon, J. M., Wood, K. D., \& Kiser, K. 2009. Promoting Vocabulary Learning with the Interactive Word Wall. Middle School Journal.

Hatch, E., \& Brown, C.1995. Vocabulary, Semantics, and Language Education. Cambridge: Cambridge University Press.

Hunt, A. \& Beglar, D. 1998. Current Research and Practice in Teaching Vocabulary. Retrieved 2 Mey 2013 fromhttp://www.jaltpublications.org/tlt/files/98/jan/hunt.html Juma, Badriya Al-Salmi and Batinah South Region. Teaching Vocabulary Using Shared Reading and Flashcards. Retrieved 12 Mey 2013 from http://www.jaltpublications.org/tlt/files/98/jan/hunt.html

Laufer, B.1997. The lexical Plight in second language Reading In J. Coady \& T. Hucking (Eds), Second vocabulary acquisition. Cambridge: Cambridge University Press

Ma'unah. Statistic Method, taught in sixth semester, IAIN Sunan Ampel Surabaya (English Department), 2008

Moir, J., \& Nation, P. (2008). Vocabulary and Good Language Learners: Lessons from Good Language Learners. Cambridge: Cambridge University Press.

Mondria, J. A., \& Mondria-de Vries, S. 1994. Efficiently Memorizing Words with the Help of Word Cards and "Hand
Computer": Theory and Applications. System.

Nagy, W., \& Herman, P. 1987. Breadth and Depth of Vocabulary Knowledge: Implication for Acquisition and Instruction. Hillsdale: Lawrence Erlbaum.

Nation, I.S.P.1990. Teaching and Learning Vocabulary. New York: Newbury house

Nation, I.S.P. 2001. Learning Vocabulary in another Language. Cambridge: Cambridge University Press.

Neuman, S. B., \& Dwyer, J. 2009. Missing in Action: Vocabulary Instruction in Pre$K$. The Reading Teacher.

Nicholson, T. (1998). The Flashcard Strikes Back. The Reading Teacher.

Palka, E. (1988). Using Cards to Revise and Practice Language Items. ERIC Document 302-093.

Rosa Ma Lopez Campillo. Teaching and Learning Vocabulary: an Introduction for Englsh Student

Schmitt, N. Schmitt, D. 1995. Vocabulary Notebooks: Theoretical Underpinnings and Practical Suggestions. ELT Journal, 49(2), 133-143.

http://dx.doi.org/10.1093/elt/49.2.133

Schmitt, N. 2000. Vocabulary in Language Teaching. Cambridge, New York, Cambridge University Press.

Subana et al. Statistik Pendidikan, CV. Pustaka Setia:Bandung, 2000.

Tan, A., \& Nicholson, T. (1997). Flash Cards Revisited: Training Poor Readers to Read Words Faster Improves their Comprehension of Text. Journal of Educational Psychology, 89, 276-288.

Thornbury, S. 2002. How to Teach Vocabulary. Essex: Pearson 
R E F O R M A J u r n a l P e n d i d i k a n \& P e m b e l a j a r a n

ESL.McCarthy, M., O'Dell, F. (2008).

Academic Vocabulary in Use, Cambridge:

Cambridge University Press. 23

Ur, Penny. 1996. A Course in Language

Teaching. Cambridge University

Press:Great Britain.

The American Heritage Dictionary

William P. Bintz, Teaching Vocabulary Across the Curriculum. Retrieved 12 Mey 2013 from http://www.jaltpublications.org/tlt/files/98/jan/hunt.html

www.wikipedia.com

www.unhalu.ac.id. 